\title{
JUURNAL.RU
}

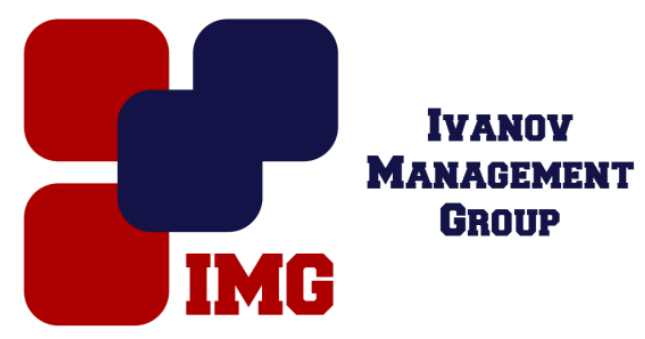

Тулпаров Д.Х. Северо-Кавказская государственная гуманитарно-технологическая академия, Юридический институт Черкесск, Россия

doi: $10.18411 / 1 \mathrm{j}-31-05-2017-54$

idsp 000001:1j-31-05-2017-54

\section{Уголовно-правовые проблемы преступлений, связанных с организацией и участием в незаконных вооруженных формированиях}

\section{Аннотация}

Зашита от преступных посягательств прав и свобод человека и гражданина, провозглашенных Конституцией Российской Федерации являются на сегодняшнее время наиболее актуальными. Речь идет о создании и деятельности организаций, которые подрывают стабильность и спокойствие населения, причиняют материальный вред, и в большинстве случаев влекут человеческие жертвы.

Ключевые слова: преступность, бандитизм, незаконные вооруженные формирования, доктрина, уголовная ответственность.

Ст. 13 Конституции РФ запрещает «создание и деятельность общественных объединений, цели или действия которых направлены на насильственное изменение основ конституционного строя и нарушение целостности Российской Федерации, подрыв безопасности государства, создание вооруженных формирований, разжигание социальной, расовой, национальной и религиозной розни». Также уголовную ответственность за организацию незаконного вооруженного формирования и участие в нем предусматривает Уголовный Кодекс РФ (ст. 208).

В структуре роста преступности определенную долю занимают бандитизм, наемные и заказные убийство, терроризм и множество других преступлений, связанных с совершением вооруженных нападений, совершений поджогов и 
взрывов. В приведенной классификации преступлений одну из ведущих ролей можно отвести организации незаконного вооруженного формирования и участия в нем, так как при взаимодействии именно с подобного рода организациями и совершаются большинство тяжких и особо тяжких преступлений.

Сам факт существования незаконных вооруженных формирований ставит под сомнение способность государства устранять создающиеся угрозы жизни и здоровья граждан, общественной безопасности и порядка, а также целостности России. По мере разрастания таких организаций, увеличивается и степень недоверия граждан к государству. Роль государства и органов власти в предупреждении подобного рода деяний и вера народа в них должна основываться на определенной результативности.

Как отметил в своем Послании Федеральному Собранию Российской Федерации от 25.04.2005г. Президент России В.В. Путин «укрепление правопорядка неотделимо от устранения источников террористической агрессии на территории России. Стоит только проявить слабость, мягкотелость - потерь будет неизмеримо больше, и они могут обернуться общенациональной катастрофой».

В доктрине уголовного права отсутствует единообразие мнения относительно того какие признаки характеризуют данный состав преступления. Так, в уголовно-правовой науке существует несколько мнений относительно объекта преступления, предусмотренного ст.208 УК РФ. Так Ф.А. Узбеков в своем исследовании говорит о том, что данный состав преступления является многообъектным. Мнение же Е.А. Маслаковой является для нас более объективным, которая отмечает, что «организация незаконного вооруженного формирования или участие в нем является однообъектным преступлением, непосредственным объектом которого является общая безопасность, под которой следует понимать совокупность отношений, обеспечивающих состояние защищенности личности, общества, государства от внешних и внутренних угроз». Законодательно, в самой статье 208 УК не предусматривается указание на цель создания незаконного вооруженного формирования, что подтверждает нашу теорию об однообъектности рассматриваемого состава. Объективная сторона данного деяния предусматривает совершение хотя бы одного из указанных альтернативных действий:

- создание вооруженного формирования (объединения, отряда, дружины или иной группы); 
- руководство таким формированием;

- финансирование этого формирования;

- участие в нем.

Субъектом преступления является физическое вменяемое лицо, достигшее шестнадцатилетнего возраста. Однако многие ученые сходятся во мнении, что необходимо и целесообразно снизить возрастной предел для привлечения к уголовной ответственности, так как отмечается высокий уровень совершения преступлений в незаконных вооруженных формированиях лицами с 14 лет. К данному мнению присоединяются и специалисты в области ювенальной юстиции, отмечающие способность 14-летних подростков осознавать фактический характер и степень общественной опасности рассматриваемого преступления.

Субъективная сторона данного деяния выражается в вине в форме прямого умысла. Законодательно в статье 208 УК не предусматривается наличие определенных целей и мотивов, что может служить проблемой в правоприменительной практике. Так, например, основным отличающим признаком организации незаконного вооруженного формирования или участия в нем от организации террористического сообщества и участия в нем (ст. 205.4 УК РФ), или же от бандитизма (ст. 209 УК РФ), является цель совершения таких действий. Как правило, указанные нами составы преступлений, предусматривают наличие таких целей как:

- осуществление террористической деятельности;

- для подготовки или для совершения одного или нескольких преступлений;

- пропаганды, оправдания или поддержки терроризма;

- нападения на граждан или организации и др.

В организации вооруженного формирования указание на цель отсутствует. Н. Г. Иванов считает, что банда и незаконное вооруженное формирование - это два состава преступлений, которые предусматривают в себе все признаки групп, описанных в Общей части УК РФ, отличающиеся от иных вооруженностью, но очень схожие между собой. «А разве незаконное вооруженное формирование не может планировать нападения на граждан или организации? В то же время разве банда - законное вооруженное формирование?» - задает себе вопрос автор.

Таким образом, подводя итоги, необходимо отметить, что как в теории, так и в практике существуют проблемы квалификации рассматриваемого 
преступления, а также остаются актуальными вопросы отграничения смежных составов преступлений. Эти вопросы требуют более глубокого и детального научного исследования для соответствующего теоретического разъяснения или правильной реализации этой нормы на практике.

1. Аджиев А. Д. Организация незаконного вооруженного формирования или участие в нем: уголовно-правовые аспекты противодействия: Автореф. дис. ... канд. юрид. наук. Краснодар, 2009. С. 23.

2. Иванов Н. Г Нюансы уголовно-правового регулирования экстремистской деятельности как разновидности группового совершения преступлений // Государство и право. 2003. № 5. C. 45 .

3. Маслакова Е. А. К вопросу об организации незаконного вооруженного формирования или участия в нем // Военно-юридический журнал, 2014, № 3. С.

4. Послание Президента России Владимира Путина Федеральному Собранию Российской Федерации // Щит и меч. 2005.28 aip.—5 мая 2005. С. 1.

5. Узбеков Ф. А. Уголовно-правовые аспекты ответственности за организацию незаконного вооруженного формирования или участие в нем: Автореф. дис. ... канд. юрид. наук. Саратов, 2005. С. 15. 